\title{
PENYULUHAN FORMULASI SEDIAAN SERBUK TABUR PERONA PIPI EKSTRAK ETANOL BUAH SEMANGKA (Citrullus lanatus)
}

\author{
Sari Theresia Bukit ${ }^{1 *}$,Dewi Kartika² Jhon Patar Sinurat ${ }^{1}$ \\ ${ }^{1}$ Program Studi Teknologi Laboratorium Medik, Institut Kesehatan Medistra Lubuk Pakam \\ ${ }^{2}$ Program Studi Farmasi, Institut Kesehatan Medistra Lubuk Pakam \\ JIn. Sudirman No.38 Lubuk Pakam, Kabupaten Deli Serdang, \\ Sumatera Utara - Indonesia \\ *email korespondensi author: saritheresiaB@gmail.com
}

DOI $10.35451 /$ jpk.v1i1.625

\begin{abstract}
Abstrak
Salah satu buah di Indonesia yang dapat dimanfaatkan dalam bidang kosmetik adalah semangka. Warna merahnya menunjukkan kandungan likopen yang tinggi, pigmen alami sebagai pewarna dalam formulasi kosmetik dekoratif, terutama perona pipi. Tujuan dari penelitian ini adalah untuk mengetahui apakah ekstrak semangka dapat digunakan sebagai pewarna pada sediaan perona pipi dan untuk mengetahui formulasi perona pipi semangka (Citrullus lanatus) tidak menyebabkan iritasi kulit saat digunakan. Ekstrak diperoleh dengan cara maserasi menggunakan etanol $96 \%$. Formula perona pipi menggunakan pewarna dari buah semangka dengan konsentrasi $15 \%$, 20\%, dan 25\%. Evaluasi sediaan meliputi homogenitas, organoleptik, uji iritasi, uji $\mathrm{pH}$. Hasil penelitian menunjukkan bahwa homogenitas, organolepti, dan $\mathrm{pH}$ sediaan tetap stabil selama 14 hari penyimpanan. Hasil uji iritasi tidak menunjukkan adanya iritasi.
\end{abstract}

Kata kunci : Blush on, ekstrak semangka, Evaluasi sediaan perona pipi

\begin{abstract}
One of the fruits in Indonesia that can be used in the cosmetic sector is watermelon. Its red color indicates the high content of lycopene, a natural pigment as a coloring agent in decorative cosmetic formulations, especially blusher. The purpose of this study was to determine whether watermelon extract can be used as a dye in blusher preparations and to determine the formulation of watermelon (Citrullus lanatus) blusher does not cause skin irritation when used. The extract was obtained by maceration using $96 \%$ ethanol. The blush formula uses dye from watermelon with a concentration of $15 \%, 20 \%$, and $25 \%$. The evaluation of preparations includes homogeneity, organoleptic, irritation test, $\mathrm{pH}$ test. The results showed that homogeneity, organolepti, and $\mathrm{pH}$ of the preparation remained stable for 14 days of storage. The results of the irritation test did not show any irritation.
\end{abstract}

Keywords : Blush, Watermelon extract, Evaluate blusher preparations

\section{Pendahuluan}

Setiap wanita memiliki kecenderungan serupa yaitu ingin terlihat cantik dan menyenangkan untuk dipandang sehingga produk kosmetik penting untuk memenuhi kebutuhan pribadi. Masyarakat cenderung memanfaatkan kembali bahan-bahan alam bagi kesehatan, obat-obatan dan kosmetik dari tanaman. Oleh karena itu pemakaian tanaman sebagai bahan obat dan kosmetik sudah dibuktikan kebenaran khasiat oleh para peneliti terdahulu. 
Received: 12 April 2021 ::Accepted: 23 June 2021 :: Published: 30 June 2021

Berdasarkan

penggunaannya, kosmetik dibedakan menjadi kosmetika perawatan dan kosmetika dekoratif/tata rias. Salah satu bentuk sediaan nya adalah pemerah pipi atau sering disebut blush on. Apabila di aplikasikan akan menghasilkan rona segar dan memperjelas keindahan tulang pipi, sehingga umumnya pemerah pipi mempunyai warna yang menarik (Schlossman, 2001 Hilyatussa'adah, 2018). Perona pipi tersedia dalam berbagai macam sediaan, salah satunya dalam sediaan serbuk tabur.

Dalam bidang formulasi kosmetik dikenal beberapa zat warna diantaranya pewarna organik, garam logam tidak larut, zat alam, serta zat warna khusus untuk rambut (tidak termasuk bulu mata) (Syarifah, 2019). Berdasarkan sumbernya ada dua jenis pewarna yaitu alami yang diperoleh dari alam dan sintetis berasal dari perpaduan dua atau lebih senyawa kimia (Afriyeni,2016).

Salah satu bahan alam yang dapat digunakan sebagai pewarna pada perona pipi adalah buah semangka yang mengandung banyak air (sekitar $92 \%$ ) dan mengandung likopen sebesar 48,8 $\%$. Buah semangka berpotensi sebagai pewarna alami pada perona pipi karna mengandung pigmen likopen. Likopen merupakan pigmen alami yang memberikan warna merah pada tomat, jambu biji, semangka, dan anggur merah (Holden et al., 1999 dalam Nur, 2015).

\section{Metode}

Kegiatan pengabdian ini dilakukan melalui seminar menggunakan metode ceramah, tanya jawab dan demonstrasi. Untuk mengidentifikasi metabolit sekunder yang terkandung dalam buah semangka adalah melalui skrining fitokimia. Proses ekstraksi buah semangka dilakukan menggunakan metode maserasi.

Prosedur yang digunakan dalam kegiatan pengabdian ini adalah sebagai berikut:

\section{a. Tahap Persiapan}

Mempersiapkan materi sosialisasi dan media pendukungnya. Peralatan dan
Bahan yang digunakan juga dipersiapkan

\section{Alat}

Alat-alat yang digunakan antara lain: $\mathrm{pH}$ meter, peralatan kaca, kertas saring, timbangan, waterbath, tissue, kertas perkamen, ayakan (mesh 60, 100), spatula, sudip, wadah blushon, dan toples.

\section{Bahan}

Bahan tumbuhan yang digunakan dalam kegiatan ini adalah Buah semangka yang sudah di ekstraksi (citrullus lanatus) beserta bahan yang digunakan dalam formula pembuatan sediaan perona pipi.

\section{b. Tahap Pelaksanaan}

Kegiatan penyuluhan dilakukan secara langsung terhadap peserta melalui kegiatan seminar. Kegiatan ini diharapkan dapat membuka dan menambah wawasan para peserta. Ekstrak buah semangka yang sudah diperoleh melalui proses ekstraksi di buat sediaan perona pipi sesuai dengan formula yang sudah ditentukan. Sedian yang sudah jadi di ujikan ke peserta seminar.

\section{Hasil dan Pembahasan}

Hasil formulasi sediaan dapat dilihat pada tabel berikut:

Tabel 1: Hasil Formulasi sediaan perona pipi

\begin{tabular}{l|l}
\hline \multicolumn{1}{c|}{ Formula } & \multicolumn{1}{c}{ Hasil } \\
\hline F1 (15\%) & Merah muda-putih \\
\hline F2 (20\%) & Merah jambu \\
\hline F3 (25\%) & Merah keunguan \\
\hline
\end{tabular}

syarat homogenitas warna yang baik adalah zat warna harus terbagi rata di dalam pembawa serbuk. Hasil uji homogenitas dapat dilihat pada tabel berikut.

Tabel 2: Hasil Pengamatan Uji Homogenitas pada Sediaan Perona Pipi

\begin{tabular}{c|c|c|c}
\hline \multirow{2}{*}{ Formula } & \multicolumn{3}{|c}{ Pengamatan hari ke- } \\
\cline { 2 - 4 } & $\mathbf{0}$ & $\mathbf{7}$ & $\mathbf{1 4}$ \\
\hline F1 (15\%) & $\mathrm{H}$ & $\mathrm{H}$ & $\mathrm{H}$ \\
\hline F2 (20\%) & $\mathrm{H}$ & $\mathrm{H}$ & $\mathrm{H}$ \\
\hline F3 (25\%) & $\mathrm{H}$ & $\mathrm{H}$ & $\mathrm{H}$ \\
\hline
\end{tabular}

Keterangan: $\mathrm{H}=$ Homogen 
Sediaan perona pipi dianalisis melalu pengamatan organoleptikmeliputi warna, bau, dan tekstur. Hasil Uji organoleptik dapat dilihat pada tabel

Dari hasil uji iritasi juga telah terbukti bahwasanya sediaan ini tidak mengiritsi. Sementara untuk pengukuran $\mathrm{pH}$ bisa dilihat ditabel berikut:

Tabel 3. Uji PH sediaan

\begin{tabular}{c|c}
\hline Formula & pH \\
\hline F1 $(15 \%)$ & 6 \\
\hline F2 $(20 \%)$ & 7 \\
\hline F3 $(25 \%)$ & 7 \\
\hline
\end{tabular}

Tabel 4. Pengamatan sediaan

\begin{tabular}{c|c|c|c|c}
\hline \multirow{2}{*}{ Formula } & \multirow{2}{*}{ Parameter } & \multicolumn{3}{|c}{$\begin{array}{c}\text { Pengamatan hari } \\
\text { ke- }\end{array}$} \\
\cline { 3 - 5 } & & $\mathbf{0}$ & $\mathbf{7}$ & $\mathbf{1 4}$ \\
\hline \multirow{2}{*}{$\begin{array}{c}\text { F1 } \\
(15 \%)\end{array}$} & Warna & $\mathrm{MP}$ & $\mathrm{MP}$ & $\mathrm{MP}$ \\
\cline { 2 - 5 } & $\mathrm{Bau}$ & $\mathrm{BK}$ & $\mathrm{BK}$ & $\mathrm{BK}$ \\
\cline { 2 - 5 } & Tekstur & $\mathrm{H}$ & $\mathrm{H}$ & $\mathrm{H}$ \\
\hline \multirow{2}{*}{$\begin{array}{c}\text { F2 } \\
(20 \%)\end{array}$} & Warna & $\mathrm{MJ}$ & $\mathrm{MJ}$ & $\mathrm{MJ}$ \\
\cline { 2 - 5 } & $\mathrm{Bau}$ & $\mathrm{BK}$ & $\mathrm{BK}$ & $\mathrm{BK}$ \\
\cline { 2 - 5 } & Tekstur & $\mathrm{H}$ & $\mathrm{H}$ & $\mathrm{H}$ \\
\hline \multirow{3}{*}{$\begin{array}{l}\text { F3 } \\
(25 \%)\end{array}$} & Warna & $\mathrm{MK}$ & $\mathrm{MK}$ & $\mathrm{MK}$ \\
\cline { 2 - 5 } & Bau & $\mathrm{BK}$ & $\mathrm{BK}$ & $\mathrm{BK}$ \\
\cline { 2 - 5 } & Tekstur & $\mathrm{H}$ & $\mathrm{H}$ & $\mathrm{H}$ \\
\hline
\end{tabular}

Hasil yang diperoleh dari kegiatan pengabdian ini adalah sebagai berikut:

1. Materi seminar dapat dipahami oleh peserta seminar yang dibuktikan melalui pre test dan post test yang diberikan.

2. Peserta seminar dapat mengetahui prosedur formulasi sediaan tabor perona pipi dari ekstrak buah semangka.

3. Peserta seminar mendapat pengetahuan baru mengenai manfaat dari buah semangka yang dapat dijadikan sebagai pewarna alami dalam kosmetik.

4. Kesimpulan

a. Ekstrak Buah semangka dapat digunakan sebagai pewarna alami dalam formulasi sediaan perona pipi.

b. Semakin banyak ekstrak buah semangka yang diberikan untuk formulasi, warna yang dihasilkan semakin pekat.

\section{Ucapan Terimakasih}

Pengabdi menyampaikan ucapan terima kasih kepada:

a. Lembaga Penelitian dan Pengabdian Kepada Masyarakat (LPPM) Institut Kesehatan Medistra Lubuk Pakam.

b. Semua pihak yang telah membantu dan ikut berpartisipasi dalam kegiatan penyuluhan ini

\section{Datar Pustaka}

Baki G., Alexander K.S. (2015).Introduction to Cosmetics Formulations and Technology, John Wiley\& Sons, Inc.,Hoboken, New Jersey.

Cristin, novia. (2015). Skrining fitokimia dan uji aktivitas antioksidan sari daging buah semngka (Citrullus lanatus (Thunb.) Matsum. \& Nakai) dengan metode DPPH $(1,1$ diphenyl-2-picrylhydrazil). Skripsi. Fakultas Farmasi Univeristas Sumatera Utara.

Ditjen POM. (2011). Farmakope Indonesia. Edisi IV.Jakarta: Depertemen Kesehatan RI.

Harbone, J.B. (1987). Metode Fitokimia, Penuntun Cara Modern Menganalisa Tumbuhan. Terjemahan Kosasih Padmawinata. Edisi II. Bandung: ITB Press.

Menkes, RI. (2010). Izin Produksi Kosmetika. Jakarta:Kementrian Hukum dan HAM. Hal 3.

Ramadhan, Muhammad Nizar., Amaliyah Wahyuni., Dwi Rizki Febrianti (2019). Formulasi dan Evaluasi sifat fisik sediaan sabun mandi padat ekstrak etanol Daun Bawang Dayak (Eleutherine palmifolia (L). 